\title{
ECONOMIC TOOLS OF REALIZATION STRATEGIC MANAGEMENT IN UNIVERSITIES
}

\author{
Yurii Safonov' ${ }^{1}$, Valeria Marichereda ${ }^{2}$, levgen Bazhenkov ${ }^{3}$
}

\begin{abstract}
The main purpose of the paper is to analyze the economic instruments for the implementation of strategic management in universities. Methodology. This study combines economic and managerial analysis of higher educational management. In this study, a set of general scientific and special research methods was used to achieve the goal of the study. The method of logical analysis of the literature was used. The functional, structural and economic analysis was used with purpose to research the main economic tools of realization strategic management in universities. Comparative analysis and synthesis methods were used to study different types of economic and strategic instruments. Using the method of generalization, conclusions and recommendations were made to improve the mechanism of strategic management used in the educational sphere. As the information base for the study the works of scholars in the field of strategic and educational management were used. Findings. The article analyzes the process of strategic management based on the concept of balanced scorecard in the university. The authors used an adaptive mechanism to develop and implement a strategy in the management system of the university. A set of indicators assessing the process of implementing strategic management was proposed. Management influence indicators, primary control factors, development indicators and financial outlook were analyzed. The management system of the university on the basis of strategic management was described, in which the correspondence between the economic indicators of the university and its organizational structure is presented. Challenges to the further implementation of strategic management in developing countries are considered. Practical implications. The results of this study form the methodological and practical basis for improving management processes in developing countries. The results of the study can become the basis for the formation of effective educational management, ensuring the continuous development of universities.
\end{abstract}

Key words: strategic management, university, educational management, higher education, development.

JEL Classification: 123

\section{Introduction}

Higher education in developing countries, like other production and non-production spheres, is increasingly feeling the pressure of the market. Being bound by new responsibilities and freedoms, the managerial processes in universities are becoming more and more adequate to those used in the field of entrepreneurship. Higher education institutions have faced a number of problems related to effective management processes, among which are: (a) the unsuitability of management structures to market conditions; (b) the focus on current operational activities; (c) the presence of social burden, which is not always consistent with commercial activities; (d) the availability of a wide range of diverse resources; (e) complex functional connections.

The contradiction between the existing management technologies and the conditions of external environment requires changes in the organization of university management, primarily in terms of interaction with the external environment, which is the society as a whole with its educational

\footnotetext{
Corresponding author:

${ }^{1}$ Institute of Education Content Modernization, Ukraine.

Kyiv National Economic University named after Vadym Hetman, Ukraine.

E-mail: sum1971@ukr.net

ORCID: https://orcid.org/0000-0001-5623-1965

${ }^{2}$ Odessa National Medical University, Ukraine.

E-mail: valmar@i.ua

ORCID: https://orcid.org/0000-0002-1611-3654

${ }^{3}$ State Scientific Institution "Institute for Modernization of Educational Content", Ukraine.

E-mail: 1spartak@ukr.net

ORCID: https://orcid.org/0000-0003-0117-294X
} 


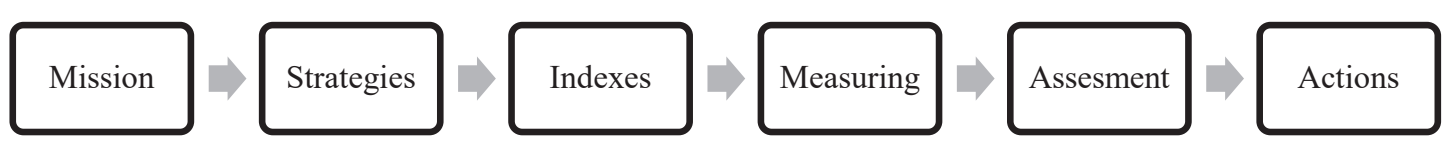

Figure 1. Steps of strategies' creating and realization

Source: Luxton, 2005

needs and demands, as well as individual consumers of educational services represented by enterprises nd organizations.

Management in universities in today's environment must ensure flexibility and adaptability to market conditions, including a long-term, strategic period (Ofori, Atiogbe, 2012). In today's operating environment of organizations, an important stage of strategic management is not only to develop a rational strategy, but also to ensure its cost-effective implementation. A qualitatively new approach can be based on the use of an adaptation mechanism to implement strategies.

Thus, the goal of this paper is to analyze the economic tools of realization strategic management in universities.

This study combines economic and managerial analysis of higher education management. In this research, a set of general scientific and special research methods was used to achieve the goal of the investigation. The method of logical analysis of the literature was used. In order to study the main economic instruments of strategic management implementation in universities, functional, structural and economic analysis was used. Comparative analysis and synthesis methods were used to investigate different types of economic and strategic instruments. Using the method of generalization, conclusions and recommendations were made to improve the mechanism of strategic management used in the educational sphere. As the information base for the study the works of scholars in the field of strategic and educational management were used.

\section{Discussion and research results}

The classic process of developing and implementing a strategy consists of six stages (Figure 1) (Luxton, 2005).

In modern conditions, the main disadvantages of this algorithm are:

- lack of a step-by-step control mechanism, and, consequently, an adaptive principle for the formation and implementation of strategic management;

- lack of an economic mechanism for implementing the strategy.

In this regard, the process of strategy development and implementation can be clarified and expanded as follows Figure 2.

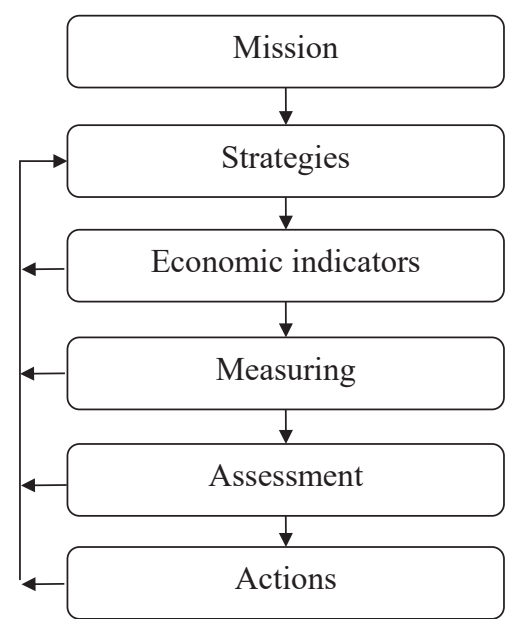

Figure 2. Steps of adaptive strategies' creating and realization

This approach assumes:

1) use of the economic indicators of the university's activities in the following areas: financial perspective, marketing perspective, internal processes and development prospects (setting up a balanced scorecard (BSC)) for analytical process;

2) adjustment of the strategy, which is a step-bystep assessment of indicators or actions in a real unstable environment and is characterized by feedback.

The adaptive approach to the strategy's implementation is resulted from the changes in the external environment, as well as functional relationships within the university (transition from a centralized management system to a more flexible one) (Guerra et al., 2017). The adaptive mechanism, on the one hand, will allow universities to operate effectively in the market of educational services, and on the other hand, will ensure the functioning of the economic mechanism of inner-university management (Khadija Hamdani \& Salah Koubaa, 2021).

The adaptive mechanism assumes:

1. Allocation of two management contours: strategic in the functional context (determines the general directions of development, formed on the basis of the mission and goals of the university; characterized by common basic indicators) and operational-tactical (includes elements of private regulation and is a tool for implementing the strategy; characterized by indicative indicators, tied to certain types of activities). At this level, the commercial principle of the university manifests itself. Thus, the gap between operational and strategic planning and management is bridged (Figure 3 ). 
2. Allocation of independent profit centers (strategic economic zones), which can be faculties or departments. In this regard, the operational and tactical level of management can be considered as the level of interacting subsystems (profit centers), and these subsystems are in some way self-organizing. Self-organization is understood as "the property of a system to acquire a spatial, temporal and functional structure without a specific external influence imposing a functioning system".

3. Giving profit centers economic independence, which will ensure the growth and strengthening of horizontal ties between subsystems, with their subsequent replacement of the vertical hierarchy without premature destruction of the latter. At the same time, the actions of profit centers (subsystems) will be regulated on the basis of performance indicators determined by the university's strategy and representing a certain corridor within which the actions of subsystems are possible.

Thus, as a new methodological approach to the formation and implementation of the strategy of the university in a dynamic external environment is proposed to use the ability of its structural units to self-organization. That is, there is a transition to a qualitatively new level of strategy formation, which is not the management of the organization, but the processes of self-organization on the basis of indicative planning.

The self-organizing process itself, in turn, controls the organization. The chain of interactions in the system under consideration can be represented as follows: the object of management (faculties, departments) is a supplier of a "finished product" in the market of educational services (Goldman \&
Salem, 2015). If the supply of educational services matches the demand of consumers, the system operates in a stationary mode, while the university's administration provides current funding, material support and quality control.

In practice, the changing external environment constantly dictates new conditions that require the university to respond adequately, both at the operational, tactical and strategic levels, which is provided by the management system presented in Figure 3.

In this case, the "imbalance" between supply and demand in the market of educational services forms the factors of university management.

Thus, input information is the primary factor of management and represents information about the range of specialties, prices for educational services, the required quality of specialists and trends in these data. Based on the primary information, control actions are developed that directly characterize the interaction between the object and the subject of management, at the strategic, operational and tactical levels (Figure 3).

Primary factors and managerial influence predetermine the set of indicators. Indicative regulation is an indirect regulation of autonomous subsystems, which provides them a perspective of economic development and at the same time sets some limits on the activities (based on indicators). It includes components of general regulation and self-regulation; it is an assessment and control mechanism. The indicators reflect the boundaries within which the system can function and develop sustainably. This control mechanism involves a feedback system and, depending on the results, can

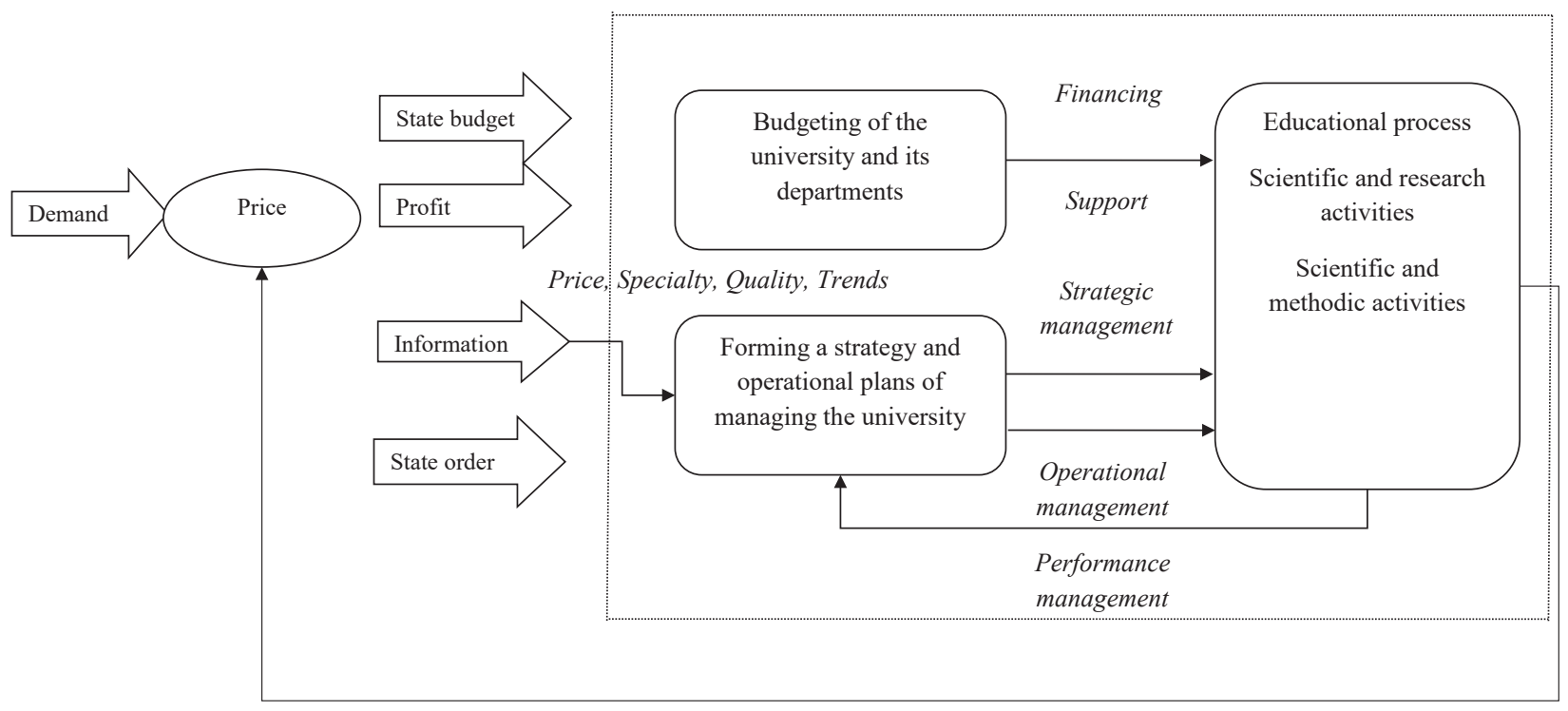

Supply of educational services

Figure 3. The university management system 
serve to revise the company's mission, strategic goals, or overall strategy (Macdonald, 2019).

Primary control factors are defined as follows:

1. Meeting the needs of consumer groups of educational services lies in two spheres: (a) demand studies - demand forecasting - product lifecycle development; (b) proposal studies - competitors studies - competitive assessment.

The following indicators are considered: recruitment by specialties, competition between applicants, services' price, employment level of graduates, value of services for consumers, availability of distribution channels for the educational product (equipment, building, IT), communication with consumer groups, training of technical personnel.

2. Meeting the needs of employers and the state as the main employer.

To the above indicators are added the following: forecasting the demand of enterprises for the university's specialties; availability of job offers; training.

3. Recognition of the university as a center of innovation.

The indicators are: development of new directions; the volume of innovative developments in the market; the use of IT in educational process; participation of the university in programs for the development of society (social orientation); contribution to the sectoral result of scientific and technical activities (share in the sectoral volume of R\&D); the university's share in the scientific and technical potential of the industry.

Managerial influence is formed in the following areas:

I. Internal processes, which are aimed at providing the material and technical basis for the implementation of the adjusted goal (ensuring the quality of educational services), namely:

1. Personnel direction: the proportion of highly qualified specialists, the dynamics of the personnel number, age characteristics of the personnel.

2. Material and technical direction: equipment depreciation, equipment renewal rate, the ratio of active and passive part of fixed assets.

3. Creation of an effective accounting and control system.

II. The development perspective, which is determined in the following areas:

1. Innovation orientation: assessment of scientific activity, the rate of change in the amount of R\&D carried out, the proportion of $\mathrm{R} \& \mathrm{D}$ performed to improve the economic potential of the country.

2. Opening new strategic directions.

3. Improving the quality of education: increasing the employees' professional level, improving the material and technical base, the effective use of material and technical base, the use of IT in the educational process.

However, another category of factors affecting both the internal and external processes of the university should be taken into account. This category represents financial factors that, on the one hand, link the university with the external environment (through the price and income stream from the university's activities in the educational services market, as well as budgetary funds), and, on the other hand, are a regulatory mechanism in the interaction of the management (administration) and profit centers (faculties) within the management system.

The financial perspective is formed taking into account the following features of the university's activities:

- the main goal of the university is to meet the social needs of society, and the financial perspective is only a tool for the implementation of the mission;

- the main direction of the development of the financial perspective is to ensure financial potential, that is, the university's development through the cost-effective organization of activities in conditions of limited resources.

In this regard, the university's financial potential means both the financial self-sufficiency of profit centers (faculties), effective distribution and use of financial resources (Etzkowitz et al., 2008).

1. Financial self-sufficiency is the establishment by each economic unit of the university and its subdivisions of the size and structure of funds necessary for reproduction activities. The analysis of the university's financial self-sufficiency is similar to the analysis of the financial stability of commercial organizations. The indicators of autonomy and efficiency of the profit center are considered as main indicators.

2. The effective allocation and use of resources is advisable to analyze with factor-cost analysis, which allows not only to determine what was spent, but also how it was spent. The following are considered as activity's indicators: current liquidity ratio (the university must at least pay current liabilities); indicator of competitive admission for budget funding; standard cost of education (validity of the scale of payment).

The system of university's management factors considered above is embedded in the balanced scorecard (BSC) concept, developed by R. Kaplan and D. Norton and aimed at the effective implementation of strategic management (Figure 4).

For the successful implementation of the university strategy it is necessary to have a correspondence between the economic indicators of the university and its organizational structure (Audretsch, 2014). Any inconsistency requires changes in the organizational structure, namely decentralization and consideration of university faculties as profit centers, but at the same time the presence of a general administrative leadership that will manifest itself through indicative regulation. 


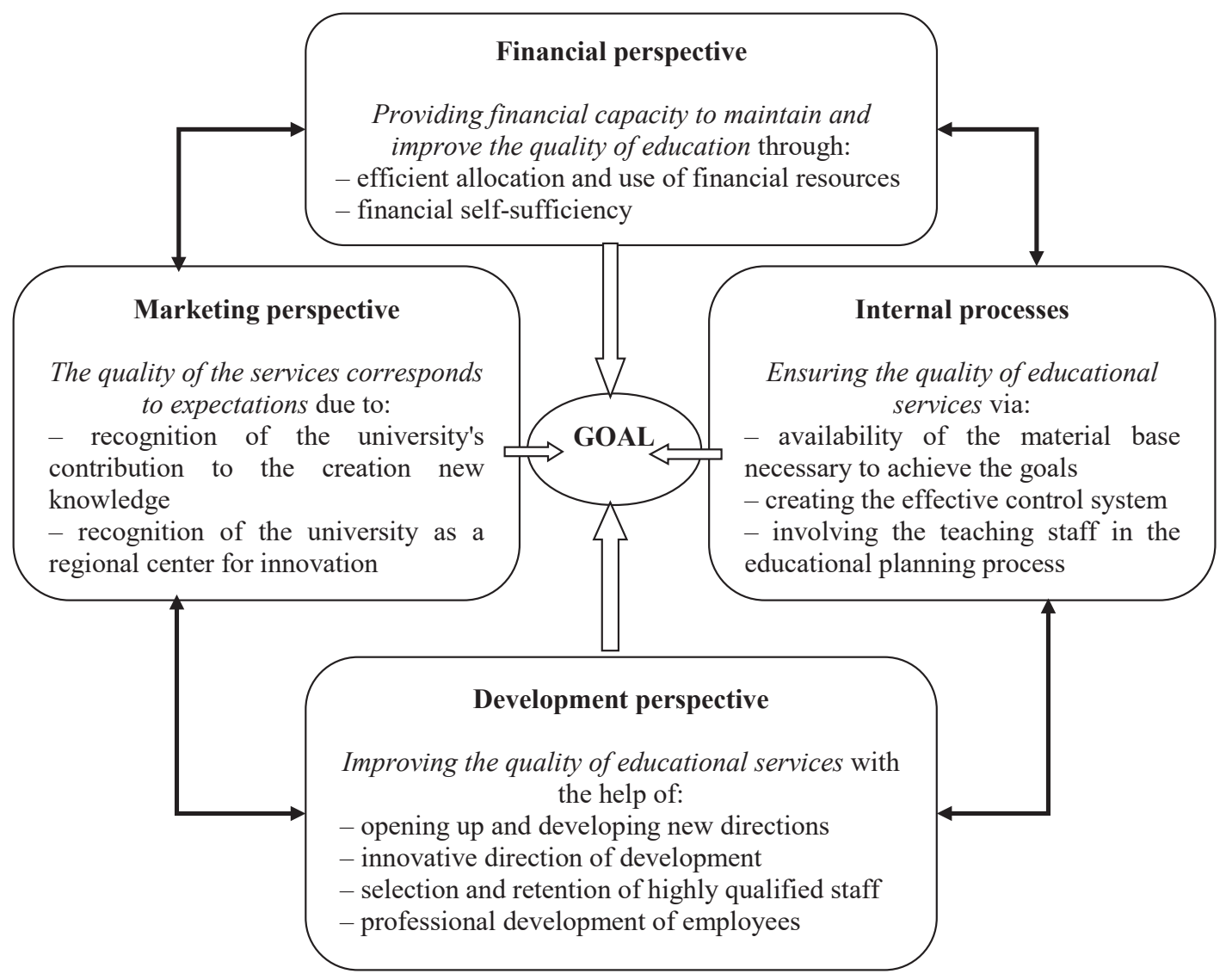

Figure 4. The balanced scorecard system for universities

Thus, defining the contours of strategic and operational-tactical control, profit centers gain economic freedom while maintaining controllability within certain limits of the adopted strategy. The limiting indicators of this "corridor of action" are the indicators defined by the strategy and presented in the balanced scorecard.

\section{Conclusions}

In modern conditions, the importance of strategic management has increased. An important feature of strategic management is the constant monitoring of changing conditions in the internal and external environment, which implies the need to respond quickly to the accumulation of a certain critical mass in them, making adjustments to individual components of the strategic management process, without changing the previously adopted general direction of the strategy (Okumus, 2003).

In our opinion, it is advisable to identify some problems of transition to strategic university management since this process is at the initial stage of elaboration in developing countries.

First, it is related to the lack of financial resources, which is a consequence of the residual principle of funding applied to the education system. And this "principle" is a reflection of the postulate of education as a non-productive sphere of society. This leads to limited financial opportunities for personnel development, improving the information environment of the university, etc.

Naturally, the shortage of financial resources arising in such conditions to ensure the functioning and development of the university, has to be compensated for account of off-budget activities. The second negative factor, which is a serious obstacle to the successful implementation of the university strategy, is quite acute here.

The fact is that all of its elements related to improving the quality of staff training, development of scientific, educational, methodological work, get wide understanding and support in the team. But as for the issues associated with the inclusion of the university in the market economic relations, the need to actively engage in attracting off-budget funds, directly participate in maintaining the university's high competitiveness in the educational services market and, moreover, in the labor market, there is no complete unity of opinion in the team. A certain part of the academic staff still maintains the belief that education as a public good and the marketplace are totally incompatible concepts. 
Therefore, the relevance of the problem of economic education and upbringing of team members, the formation of market economic between the academic staff thinking is fully preserved. This once again emphasizes the relevance and timeliness of the transition to strategic management as a qualitatively new level of leadership and the need for a decisive rejection of any elements of a spontaneous nature of management, which in the $21^{\text {st }}$ century is absolutely incompatible with the objective conditions of functioning of any complex socio-economic system.

\section{References:}

Audretsch, D. B. (2014). From the entrepreneurial university to the university for the entrepreneurial society. The Journal of Technology Transfer, 39(3), 313-321. DOI: https://doi.org/10.1007/s10961-012-9288-1 Goldman, C. A., \& Salem, H. (2015). Getting the most out of university. Strategic planning. Rand Corporation.

Guerra, F. R. et al. (2017). University Strategic Planning: A Process for Change in a Principal Preparation Program. NCPEA International Journal of Educational Leadership Preparation, 12, 1-Spring. Available at: https://files.eric.ed.gov/fulltext/EJ1145462.pdf

Etzkowitz, H. et al. (2008). Pathways to the entrepreneurial university: towards a global convergence. Science and Public Policy, 35(9), 681-695. DOI: https://doi.org/10.3152/030234208X389701

Khadija Hamdani, Salah Koubaa (2021). The strategic planning of university transformation: the case of Moroccan public universities. Projectics / Proyéctica / Projectique, 28, 51-68. DOI: 10.3917/proj.028.0051 Available at: https://www.cairn.info/revue-projectique-2021-1-page-51.htm

Luxton, A. (2005). Strategic Planning in Higher Education. All Books. Book 2. Available at: http://digitalcommons.andrews.edu/books/

Macdonald, M. (2019). Strategic plans help universities tell their story. University Affairs. Available at: https://www.universityaffairs.ca/features/feature-article/strategic-plans-help-universities-tell-their-story/

Ofori, F., \& Atiogbe, E. (2012). Strategic Planning in Public Universities: A Developing Country Perspective. Journal of Management and Strategy, 3(1). DOI: https://doi.org/10.5430/jms.v3n 1 p67

Okumus, F. (2003). A Framework to Implement Strategies in Organizations. Management Decision, 41(9), 871-882. DOI: https://doi.org/10.1108/00251740310499555 